\title{
"IMITATE ME": INTERPRETING IMITATION IN 1 CORINTHIANS IN RELATION TO IGNATIUS OF ANTIOCH
}

\author{
H. H. DRAKe WiLliams III*
}

Tyndale Theological Seminary, Amsterdam

\begin{abstract}
Several times within 1 Corinthians Paul encourages the Corinthians to imitate him. These are found at critical junctures in the epistle in 1 Corinthians $4: 16$ and 11:1. The meaning of these sections is in question from the perspective of Corinthian scholars. Several believe that Paul is appealing to apostolic power and authority to coerce the Corinthians to obey him, whereas others find him responding to social situations. This is different from the way that imitation and discipleship are presented within the writings of Ignatius of Antioch. Pauline ideas, specifically those from 1 Corinthians, are known to have influenced Ignatius of Antioch's writing, and thus Ignatius' ideas about imitation are likely to reflect the meaning that Paul intended. Ignatius specifically speaks about imitation and discipleship in several places: Ign. Eph. 1, 2, 4; 3:1-3, Ign. Magn. 4:1; 5:1-2; 9:1-6, Ign. Rom. 3:1-2; 6, 3, 1. When these passages are considered, imitation involves suffering and possibly martyrdom. Imitation is also connected to the cross of Christ and is not a means to enforce superiority. Ignatius' view of imitation would contradict the opinions of some scholars who see Paul's injunction for imitation as a claim for power. It also supplies more information to the idea than those who claim that it is simply a counter example to the social situation.
\end{abstract}

KEY WORDS: Imitation, Corinthians, Ignatius of Antioch, discipleship, suffering

Several times within 1 Corinthians Paul encourages the Corinthians to imitate him. These are found at critical junctures in the epistle such as 1 Corinthians 4:16 when Paul writes, "I urge you, then, be imitators of me". ${ }^{1}$ Imitation also occurs within 1 Corinthians 11:1 when Paul writes, "Be imitators of me, as I am of Christ". Academic Affairs and Academic Dean at Tyndale Theological Seminary which is located just outside of Amsterdam, the Netherlands. He is also a Visiting Professor at Colegiul Biblic Est European in Oradea, Romania. He is the author of Jesus Tried and True: Why the four canonical Gospels provide the best picture of Jesus published by Wipf \& Stock (2013) and the author of The Wisdom of the Wise: the presence and function of Scripture in 1 Corinthians 1:18-3:23 published by Brill (2001).

1 All Scripture texts are taken from the ESV unless otherwise noted. 
The meaning of these sections is in question from the perspective of scholars on Corinthians with a variety of reasons proposed. Some find imitation related to Pauls' concept of authority, believing that Paul's call for imitation is merely a way to reassert his jurisdiction, ${ }^{2}$ a means to assert himself as being the head of ecclesiastical authority, ${ }^{3}$ a means to motivate the Corinthians by challenging them as their friend, servant, and father, ${ }^{4}$ or an outflow of his relationship to the Corinthians as their father. ${ }^{5}$ Others find it referring to theological ideas. One scholar believes it to be an outworking of the cross of Christ $^{6}$ while others see it deriving from the suffering servant idea. ${ }^{7}$ Other scholars see the concept more directed to the social situation at Corinth. One sees it as a means to manifest unity, ${ }^{8}$ whereas another as a means to seek the common good of others, ${ }^{9}$ or a means to contradict the examples of the Sophists. ${ }^{10}$ Clearly, the interpretation of this concept is unclear.

One means that has not been sufficiently brought to bear upon this interpretation of this concept are texts from the Apostolic Fathers. Scholars such as J. B. Lightfoot, T. C. Oden, M. N. Bockmuehl, D. H. Williams, and others have urged modern interpreters of the New Testament to examine the Apostolic Fathers for the purpose of understanding portions of the New Testament. ${ }^{11}$ The Apostolic Fathers are significant sources to interpret early Christianity. They are from the period immediately following the passing of Peter and Paul and reach into the middle of the second century (c. A. D. 70-150). Several documents within this group of literature contain ideas about imitation such as the Epistle to Diognetus, Polycarp's Letter to the Philippians, Martyrdom of Polycarp, and the letters of Ignatius of Antioch. Passages within these letters likely can provide insight into how Paul understands imitation.

PERICHORESIS $11.1(2013)$ mans, 1996) 121-122. 1991), 357-58.

G. Fee, The First Epistle to the Corinthians, NICNT (Grand Rapids: Eerdmans, 1987), 183.

E. Castelli, Imitating Paul: A Discussion of Power (Louisville: Westminster/John Knox, 1991), 108. P. de Boer, Imitation of Paul: An exegetical Study (Kampen: Kok, 1962), 152-53.

L. Belleville, “'Imitate Me, Just as I imitate Christ': Discipleship in the Corinthian Correspondence", Patterns of Discipleship in the New Testament, ed. by R. N. Longenecker (Grand Rapids: Eerd-

W. Schrage, Der erste Brief an die Korinther. Teilband 1: 1Kor 1,1-6,11, EKK 7 (Zürich: Benziger,

D. M. Stanley, "Become Imitators of Me: The Pauline Conception of Apostolic Tradition”, Biblica 40 (1958): 871; R. E. Ciampa and B. S. Rosner, The First Letter to the Corinthians, PNTC (Grand Rapids: Eerdmans, 2010), 498-99.

B. Sanders, "Imitating Paul: 1 Corinthians 4:16", HTR 74 (1981): 353-363.

A. D. Clarke, Serve the Community of the Church: Christians as Leaders and Ministers, First-Century Christians in the Graeco-Roman World (Grand Rapids: Eerdmans, 2000), 226. See also A. D. Clarke, “'Be Imitators of Me': Paul's Model of Leadership”, TynBul 49 (1998): 329-60.

B. Witherington, Conflict and Community in Corinth: A Socio-Rhetorical Commentary on I and II Corinthians (Grand Rapids: Eerdmans, 1995), 145.

See further J. B. Lightfoot, The Apostolic Fathers (Grand Rapids: Baker, 1956); T. C. Oden, Ancient Christian Commentary on Scripture, 14 vols. (Downers Grove: IVP, 1998-2011); D. H. Williams, Retrieving the Tradition and Renewing Evangelicalism (Grand Rapids: Eerdmans, 1999); M. N. Bockmuehl, Seeing the Word: Refocusing New Testament Study (Grand Rapids: Baker, 2006). 
This article will specifically examine portions of the letters of Ignatius of Antioch for help in interpreting these sections in 1 Corinthians. Scholars have recognized the presence of imitation and discipleship ideas within his writing. For example Virginia Corwin writes, "The Ignatian letters have more references to imitation and discipleship than all the other apostolic fathers together". ${ }^{12}$ Scholars have also agreed that Ignatius is well-familiar with Paul's letter of 1 Corinthians, using citations and ideas similar to Paul's. In his recent article entitled "The Epistles of Ignatius of Antioch and the Writings that later formed the New Testament", Paul Foster concludes that Ignatius of Antioch had "no reasonable doubt concerning knowledge of the document". ${ }^{13}$ He notes four clear citations and several with a slight level of correspondence to 1 Corinthians. He concludes that Paul was familiar with 1 Corinthians.

In his article examining Pauline influence within Ignatius, C. B. Smith finds several influential themes from Paul within this second century writer's letters. These themes include Christology, Jewish practices within Ignatius' followers, the role of the bishop in the church, and then suffering and martyrdom. Smith even concludes by noting how the theme of imitation is also used in Ignatius as in Paul. He writes, "The theme of imitation runs strong in Ignatius' letters and the concept summarizes well the relationship between the apostle and the bishop". ${ }^{14}$

Since Ignatius was familiar with 1 Corinthians and has been noted to use the imitation theme, this article will proceed to examine several passages within the letters of Ignatius that use imitation and discipleship language. While it has been noted that these ideas converge within Ignatius' thinking, they will be examined separately, and then the results will be brought together at the end of the article. ${ }^{15}$

V. Corwin, St. Ignatius and Christianity in Antioch, Yale Publications in Religion 1 (New Haven: Yale, 1960), 228 n. 9.

13 P. Foster, "The Epistles of Ignatius of Antioch and the Writings that later formed the New Testament" The Reception of the New Testament in the Apostolic Fathers, ed. by A. C. Gregory et. al. (Oxford: Oxford University Press, 2005), 164. See 1 Corinthians 6:9-10 in Ign. Eph. 16:1; 1 Corinthians 1:18, 20 in Ign. Eph. 18:1; 1 Corinthians 5:7-8 in Ign. Magn. 10:2; 1 Corinthians 4:4 in Ign. Rom. 5:1. There is "a slight level of correspondence, some verbal similarity" between 1 Corinthians 15:8, 10a and Ign. Rom. 9.2. In a study 100 years earlier that concerned the presence of Paul's writing in Ignatius' letters, W. R. Inge lists several other possibilities. See W. R. Inge, "Ignatius", The New Testament in the Apostolic Fathers, ed. by the Oxford Society of Historical Theology (Oxford: Clarendon, 1905), 63-83.

14 C. B. Smith, "Ministry, Martyrdom, and Other Mysteries: Pauline Influence on Ignatius of Antioch", Paul and the Second Century, ed. by M. F. Bird et al., LNTS 412 (London/ New York: T \& T Clark, 2011), 55.

15 For convergence, see K. Bommes, Weizen Gottes: Untersuchungen zur Theologie des Martyriums bei Ignatius von Antiochien (Köln: Hanstein, 1976), 87-89; M. J. Wilkins, "The Interplay of Ministry, Martyrdom, and discipleship in Ignatius of Antioch”, Worship, Theology, and Ministry in the Early Church: Essays in Honor of Ralph P Martin, ed. by M. J. Wilkins et al., JSNTSup 87 (Sheffield: JSOT Press, 1992), 306; V. Corwin, St. Ignatius and Christianity in Antioch, 227; N. Brox, Zeuge und Märtyrer. Untersuchungen zur frühchristlichen Zeugnis-Terminologie, SANT 5 (München: Kösel, 1961), 215; E. Günther, “Zeuge und Märtyrer”, $Z N W$ (1956): 145.

PERICHORESIS $11.1(2013)$ 
It will examine the surrounding contexts of select passages and then draw conclusions for the way that Ignatius considered imitation. It will then evaluate how Paul may have considered this idea within his letter, comparing the conclusions with the current viewpoint of scholars.

\section{Imitation Ideas within Ignatius' Letters}

Letter to the Ephesians 1:1

The first passage that contains imitation language can be seen within the first verse of Ignatius' letter to the Ephesians which follows the greeting. The letter was written by Ignatius along his way to Rome. Representatives from several churches had met him in Smyrna. In response to their visits, he wrote letters to the church in Magnesia, Tralles, and also Ephesus. These letters urge churches to seek unity, come together under the bishop, root out heretical teaching, and pray for the church in Antioch.

The first instance of imitation occurs in Letter to the Ephesians 1:1 which reads:

Now that I have received in God your greatly loved name, which you have obtained because of your upright nature, according to the faith and love that is in Christ Jesus our Savior-for you are imitators of God (mimetai ontes theou) and have rekindled, through the blood of God, the work we share as members of the same family, and brought it to perfect completion. ${ }^{16}$

Ignatius praises God because he has received a delegation of at least five people from the church in Ephesus while he was imprisoned in Smyrna (cf. Ign. Eph. 1:32:1). There is no indication that Ignatius was known to the Ephesians, and thus, this delegation shows an important sense of identification with him. Their visit and identification with Ignatius leads to his thanks and then his declaration that the Ephesians are imitators of God.

Several other themes are notable. Imitation language is used in relationship first and foremost to God-mimètai ontes theou. A specific connection can also be seen with Christ. The use of "greatly loved name" and "righteous nature, characterized by faith in and love of Christ Jesus" reveals some identification with the person of Christ. In his comment upon this text, M. W. Holmes even interprets the loved name as that of "Christian". ${ }^{17}$

Imitation can be seen to have some connection with human examples. This can be seen by Ignatius' praise for their visit. Their trip to meet him shows their affinity with Ignatius, particularly in his suffering. Later on in the Letter to the Ephesians 1:3, he encourages the Ephesians to be like Onesimus. Ignatius writes the following.

B. D. Ehrman, The Apostolic Fathers, Volume 1: I Clement, II Clement, Ignatius, Polycarp, Didache, 2 vols., LCL (Cambridge, MA: Harvard, 2003), 201-322. All translations are taken from this source unless otherwise stated.

17 M. W. Holmes, The Apostolic Fathers: Greek Texts and English Translations, 3rd edition (Grand Rapids: Baker, 2006), 96.

PERICHORESIS $11.1(2013)$ 
Since, then, I have received your entire congregations in the name of God through Onesimus, who abides in a love that defies description and serves as your bishop in the fleshand I ask by Jesus Christ that you love him, and that all of you be like him. For blessed is the one who has graciously granted you, who are worthy, to obtain such a bishop.

The Ephesians are to be like him. In summary, then the Ephesians are to imitate God foremost, but they are also to imitate the man Onesimus who represented them.

Letter to the Ephesians 10:2-3

Later within the Letter to the Ephesians, Ignatius presents several exhortations. In Letter to the Ephesians 10:1-3, Ignatius exhorts the Ephesians to pray for other people. This section contains imitation language used in a negative as well as positive manner. On the one hand, he discourages the Ephesians from imitating something, and on the other hand, he urges them to emulate something else instead. After urging the Ephesians to pray for other people unceasingly in order that they might repent (Ign. Eph. 10:1), he urges the Ephesians not to imitate the rest of humanity. ${ }^{18}$ He then encourages them to imitate a positive example.

In response to their anger, show meekness; to their boasting, be humble; to their blasphemies, offer up prayers; to their wandering in error, be firmly rooted in faith; to their savage behavior, act civilized. Do not be eager to imitate their example (mée spoudazontes antimimēsasthai autous). Through gentleness we should be their brothers. And we should be seen to be eager to imitate the Lord (mimētai de tou kuriou spoudazōmen einai). Who was mistreated more than he? Or defrauded? Or rejected? Do this, so that no weed planted by the Devil may be found in you and you may abide in Jesus Christ both in the flesh and in the spirit, with all holiness and self-control.

The passage illustrates a strong contrast regarding imitation. The Ephesians are supposed to act opposite to the rest of the world. Isacson writes, "The contrast between imitating 'other people' and Jesus Christ is underlined as the verb antimimêsasthai is used in the first case and the noun mimètes in the second". ${ }^{19}$ When the Ephesians are called to imitate, they are asked to imitate the Lord rather than another human being. Those qualities that they are to imitate of the Lord are those that refer to Christ's suffering, namely, being wronged, cheated, and rejected. Proper imitation is an act of patient endurance through suffering. ${ }^{20}$ 
Letter to the Trallians 1:1-2

The next occurrence of imitation language within the letters of Ignatius can be found in his Letter to the Trallians. As in the Letter to the Ephesians, imitation language is found within the first chapter of his writing.

I have learned that your way of thinking is blameless and unwavering in endurance, not by force of habit but by your very nature, just as Polybius, your bishop, showed me. He arrived in Smyrna by the will of God and Jesus Christ, and so rejoiced together with me, who am in chains in Christ Jesus, so that I saw your entire congregation in him. I was exultant when I received your act of godly kindness through him, for I found that you were imitators of God (mimètas ontas theou), as I had known.

As with the Ephesians, Ignatius had not met the Trallians previously. Three times within this opening section, however, Ignatius refers to their character as expressed by their bishop Polybius. Ignatius claims that the Trallians have a blameless and unwavering mind with endurance and godly affection as evidenced by Polybius' visit. As a result of Polybius' representation of them, they all are described as being imitators of God. ${ }^{21}$

Several aspects further reveal insight into imitation. There is an emphasis on knowledge and experience. Polybius' action in rejoicing with Ignatius in his suffering exhibited that suffering is a part of imitation. Imitation language is also used in relation to one sacrificial individual who reflects the divine.

Letter to the Philadelphians 7:1-2

Imitation language continues within Ignatius' Letter to the Philadelphians. Unlike the Ephesians or the Trallians, Ignatius had visited the congregation in Philadelphia previously. As he provides a defense for this ministry activity in Philadelphia, imitation language occurs as part of his apology for his actions (Ign. Phld. 6:3-8:1).

For even if some people have wanted to deceive me according to the flesh, the Spirit is not deceived, since it comes from God. For it knows whence it comes and where it is going, and it exposes the things that are hidden. I cried out while among you, speaking in a great voice, the voice of God, "Pay attention (prosechete) to the bishop and the presbytery and the deacons". But some suspected that I said these things because I knew in advance that there was a division among you. But the one in whom I am bound is my witness that I knew it from no human source; but the Spirit was preaching, saying: "Do nothing apart from the bishop; keep your flesh as the Temple of God; love unity; flee divisions; be imitators (mimètai ginesthe Iēsou Christou hōs kai autos tou patros autou) of Jesus Christ as he is of his Father". 
In this section in which Ignatius states that he was not divisive in Philadelphia, he again employs imitation language. As in previous sections, Ignatius urges his recipients to imitate Jesus Christ. His use of imitation language in the Letter to the Philadelphians 7:1-2 is unique in adding a Trinitarian emphasis, which has not been found so far. Jesus Christ is declared to be an imitator of the Father, too. Furthermore, Ignatius declares that he is writing these words about imitation in conjunction with the Spirit who is speaking these things.

In this Letter to the Philadelphians, imitation is connected with other ideas as well. Imitation is connected with the love of unity and avoidance of division. ${ }^{22}$ Paying attention to the leadership, namely, the bishop, presbyters, and deacons is also important. ${ }^{23}$ Finally, the Philadelphians are urged to keep their flesh as the temple of God.

In his article entitled "Following in Paul's Footsteps: Mimesis and Power in Ignatius of Antioch", Reis would wish to claim from this passage that the "bishop must be imitated". ${ }^{24}$ While the bishop is to be regarded, it is claiming too much to assume that he is to be imitated. Other translators such as Ehrman and Holmes translate prosechete as "pay attention to". ${ }^{25}$ While the bishop is to be respected, so also are the council of presbyters and the deacons. Care must be exercised in this passage not to limit imitation ideas to the bishop alone. ${ }^{26}$

Letter to the Romans 6:1-3

As Ignatius is on his way to Rome, he also writes a special letter to the Romans. This letter contains his request for the Romans to allow his martyrdom to take place (Ign. Rom. 1:1-2:2). It declares how martyrdom is a true test for him and that sacrifice is true discipleship (Ign. Rom. 3:1-3; 4:1-3). It also expresses his desire to face rather than flee from martyrdom (Ign. Rom. 5:1-3). In the section that speaks of his longing for life through death, Ignatius then uses imitation language, particularly in Letter to the Romans 6:3.

Neither the ends of the world nor the kingdoms of this age will benefit me in the least. It is better for me to die in Jesus Christ than to rule the ends of the earth. That is the one I seek, who died on our behalf; that is the one I desire, who arose for us. But pains of birth have come upon me. Grant this to me, brothers: do not keep me from living; do not wish me to die; do not hand over to the world the one who wants to belong to God or deceive him by what is material. Allow me to receive the pure light; when I have arrived there, I

22 Schoedel, Ignatius of Antioch, 30.

23 Cf. Ign. Pol. 6:1; Ign. Trall. 7:2; Ign. Smyrn. 7:2; 8:1; Ign. Eph. 9:2; Ign. Magn. 1:2; 7:2. Schoedel, Ignatius of Antioch, 205.

24 D. M. Reis, "Following in Paul's Footsteps, "Following in Paul's Footsteps: Mimēesis and Power in Ignatius of Antioch", Trajectories through the New Testament and the Apostolic Fathers, ed. by A. C. Gregory et al. (Oxford: Oxford University Press, 2005), 287-306.

25 Ehrman, Apostolic Fathers, 290-91; Holmes, The Apostolic Fathers, 119; Schoedel translates this as "attend to". Schoedel, Ignatius of Antioch, 204.

26 See further the comments below on Ign. Smyrn. 12:1-2.

PERICHORESIS $11.1(2013)$ 
will be a human. Allow me to be an imitator (epitrepsate moi mimètèn einai tou pathous tou theou mou) of the suffering of my God. If anyone has him within himself, let him both understand what I want and sympathize with me, realizing the things that constrain me.

Once again, imitation is used in relation to God. Specifically, imitation language is used in relation to following the crucified Lord.

The central question of this passage concerns what Ignatius means with imitation in referring to Christ's death. Does he want to replicate Christ's death, or is he willing to follow a similar motivation that is similar to Christ's? ${ }^{27}$ Due to the several other references that have been examined thus far in which imitation is related to other matters (i.e. other people), it is better to see imitation language as a general ethical notion related to suffering, love, humility, and endurance. This is a better interpretation than seeing it as a replication of Christ's death. ${ }^{28}$

Schoedel makes several good points with reference to this passage when he writes,

[It is] questionable... to take the imitation theme in the letters as indicative of an unqualified preoccupation of the bishop with personal salvation. The one other passage in which it is joined with an emphasis on the suffering of God (expressed there in the reference to "the blood of God") has to do with the ethical consequences that flow from such imitation in the life of the Christian community (Ign. Eph. 1:1). The fact that the theme does not always have in view Christ's death or does so only to draw attention to the love of God or Christ's endurance also indicates how improbable it is to regard imitation in Ignatius as linked with the idea of cultic reenactment of the Lord's passion. And it is one-sided to find here decisive evidence that Ignatius had moved beyond the conception of following Christ in the N. T. and exalted the achievement of a special saintliness above the commitment to the Christian mission and its concern to illuminate the whole of human existence in light of the cross. ${ }^{29}$

The encouragement to follow a demeanor rather than a reenactment of Christ's death finds further support from other Apostolic Fathers. For example, Polycarp's Letter to the Philippians 8:2 states, "Let us be imitators of his endurance". Martyrdom of Polycarp 17:3 reads, "For him we worship as the Son of God, but the martyrs we

For replicating, see R. M. Grant, The Apostolic Fathers: A New Translation and Commentary, volume 4 (New York: Thomas Nelson \& Sons, 1996), 92. For seeing imitation against the backdrop of mystical practices or cult rituals, see H. Schlier, Religionsgeschichtliche Untersuchungen zu den Ignatiusbriefen (Giessen: A. Töpelmann, 1929); Th. Preiss, "La mystique de l'imitation du Christ et de l'unité chez Ignace d'Antioch”, RHPR 18 (1938): 197-241.

28 Cf. Schoedel, Ignatius of Antioch, 30; Bommes, Weizen Gottes, 39; Brox, Zeuge und Märtyrer, 205. H. von Campenhausen, Die Idee des Martyriums in der alten Kirche (Göttingen: Vandenhoeck \& Ruprecht, 1964), 76. 
love as disciples and imitators of the Lord; and rightly, because of their unsurpassable affection toward their own King and Teacher. God grant that we too may be their companions and fellow-disciples". ${ }^{30}$

Letter to the Smyrnaeans 12:1-2

Ignatius' letters contain one last clear reference to imitation. In the postscript to his letter to the Smyrnaeans, he writes the following.

The love of the brothers who are in Troas greets you; from there I am writing to you through Burrhus, whom you sent along with me, together with your brothers the Ephesians. He has refreshed me in every way. Would that everyone imitated him, as he is the embodiment of the ministry of God. But the gracious gift of God will reward him in every way. I greet the bishop who is worthy of God, the godly presbytery, the deacons who are my fellow slaves, and all individually and together in the name of Jesus Christ, in his flesh and blood, in his passion and resurrection, which pertains to both flesh and spirit, in unity with God and with you. May grace, mercy, peace, and endurance be yours at all time.

Unlike prior occurrences, imitation language is explicitly used with reference to an idealized person, Burrhus. He was the bearer of the letter (cf. Ign. Phld. 11:2) and refreshed Ignatius in every aspect. Furthermore, he was a model of service to God, and Ignatius states that he will be rewarded (cf. Ign. Smyrn. 9:2; 10:1-2). ${ }^{31}$ Besides referring to the character of an ideal person, there are other ideas found in relation to imitation. Aspects of unity are associated with imitation language. One final aspect is a reference to the passion and resurrection of Christ which is also prominent. $^{32}$

\section{Summary of Imitation Ideas}

From a survey of these passages within Ignatius' writing, imitation ideas occur frequently in relation to being like God. Particularly, these ideas often appear with relationship to the passion. Exemplary human beings are to be imitated. One should imitate a bishop like Onesimus, but one should also imitate an exemplary person like Burrhus. Imitation ideas are less likely to enforce power as imitation passages refer to the suffering Christ and the sacrifice of individuals. Imitation is used to promote unity, humility, endurance, and patience. Imitation involves suffering as the calling of all Christians in general. ${ }^{33}$ 
Discipleship Ideas within Select Passages in Ignatius' Letters

Closely related to ideas of imitation are those of discipleship. Within Ignatius' writing, the vocabulary of discipleship includes words such as mathētēs which occurs nine times and mathêteuō which occurs four times. ${ }^{34}$ There is some overlap with imitation ideas as recognized by several scholars. ${ }^{35}$ The following will investigate several select and representative passages.

Letter to the Ephesians 3:1-3

The first text concerning discipleship emerges from the Letter to the Ephesians. Ignatius has referred to imitation within his letter. Later within the letter, Ignatius picks up the theme of discipleship. In this section Ignatius encourages everyone to be subject to Ignatius and to the presbyters.

I am not giving you orders as if I were someone. For even though I have been bound in the name, I have not yet been perfected in Jesus Christ. For now I have merely begun to be a disciple (mathèteuesthai) and am speaking to you as my fellow learners (sundidaskalitais). For I have needed you to prepare me for the struggle in faith, admonishment, endurance and patience. But since love does not allow me to be silent concerning you, I decided to encourage you that you may run together in harmony with the mind of God. For also Jesus Christ, who cannot be distinguished from our life, is the father's mind, just as also the bishops who have been appointed throughout the world share the mind of Jesus Christ.

Ignatius urges discipleship, but there is humility within his plea. Instead of providing orders, he recognizes his own road of discipleship, which is in development. ${ }^{36}$ He states that he is only beginning to be a disciple (cf. Ign. Trall. 5:2; Ign. Rom. 5:3). ${ }^{37}$ Even though he is headed for martyrdom, he does not view himself as a perfect disciple. ${ }^{38}$ Even "now", he declares that he has begun to be a disciple (cf. Ign.

For mathētês see Ign. Eph. 1, 2, 4; Ign. Magn. 9:1; 9:2; 10:1; Ign. Trall. 5:2; Ign. Rom. 4:2; 5:3; Ign. Pol. 2:1; 7:1. For mathēteūo see Ign. Eph. 3:1; 10:1; Ign. Rom. 3:1; 5:1. For mathêteia see Ign. Trall. 3:2. Wilkins, "The Interplay of Ministry, Martyrdom, and discipleship in Ignatius of Antioch", 299.

Cf. Corwin, St. Ignatius and Christianity in Antioch, 227; Wilkins, "The Interplay of Ministry, Martyrdom, and discipleship in Ignatius of Antioch", 307.

36 See further Wilkins who speaks about "developmental discipleship". Wilkins, "The Interplay of Ministry, Martyrdom, and discipleship in Ignatius of Antioch”, 304-305.

37 Ignatius' Letter to the Trallians 5:2 reads, "For I myself, though I am in chains and can comprehend heavenly things, the ranks of the angels and the hierarchy of principalities, things visible and invisible, for all this I am not yet a disciple".

38 A. Mellink, "Death as Eschaton: A Study of Ignatius of Antioch's Desire for Death" (PhD diss., Universiteit van Amsterdam, 2000), 185. According to Mellink, death is a step along the way to perfection and justification.

PERICHORESIS $11.1(2013)$ 
Rom. 5:3) ${ }^{39}$ His discipleship means that he is pursuing a goal rather than declaring that he has already attained it. ${ }^{40}$

Ignatius' description of discipleship exhibits modesty rather than power or pride in other ways. He does not command them, specifically saying that he does not give "orders as if I were someone". Furthermore, he uses terminology that describes himself as an equal. He is a fellow disciple (sundidaskalitais). He does not command them as a teacher, but addresses them as fellow learners.

Letter to the Magnesians 4:1-5:2

The Letter to the Magnesians concerns the importance of staying united and following the bishop. Within this letter, there are several sections in which discipleship is mentioned. Some passages on discipleship can be found within Letter to the Magnesians 3:1-5:2. This section concerns unity and also emphasizes following the bishop (cf. Ign. Magn. 1:2; 13:1-2). It reads as follows.

And so it is fitting not only to be called Christians, but also to be Christians, just as there are some who call the person the bishop but do everything without him. Such persons do not seem to be acting in good conscience, because they do not hold valid meetings in accordance with the commandment. Since, then, these matters have an end, and the two things are set together, death and life, and each person is about to depart to his own place-for just as there are two kinds of coin, one from God and the other from the world, and each of them has its own stamp set upon it: the unbelievers the stamp of this world and the believers the stamp of God the Father, in love, through Jesus Christ. If we do not choose to die voluntarily in his suffering, his life is not in us.

The passage speaks of being a Christian rather than merely being called a Christian. This is a common theme in Ignatius' writing, word and deed matching. ${ }^{41}$ In this case, obeying the bishop is equivalent to being a Christian.

This is one of several passages within the Letter to the Magnesians which point to the importance of following the bishop, even if he is young. The Magnesians are to respect the bishop in agreement with the power of God (Ign. Magn. 3:1), and he is even compared with God (Ign. Magn. 3:1-2). The relationship between the Magnesians and their bishop is compared to that between Jesus Christ and the Father (Ign. Magn. 7:1; 13:2). Following the bishop is also declared to be true Christianity (Ign. Magn. 4:1). Discipleship and following the church leader are strongly tied together.

Ignatius' concept of a disciple is not an attained status. See Ign. Rom. 5:1 when he becomes more of a disciple, Ign. Trall. 5:2 when he is not yet a disciple, and Ign. Eph. 1:2, Ign. Rom. 4:2, and Ign. Pol. 7:1 when he will truly be a disciple through his death. Mellink, "Death as Eschaton", 209.

40 Mellink puts it well, "Discipleship is not so much an asset as a goal after which one strives". Mellink, "Death as Eschaton", 187.

41 See Eph. 14:2-15:2. See also where word and deed do not match Magn. 7:1; Trall. 7:2; Phd. 4: Schoedel, 109.

PERICHORESIS 11.1 (2013) 
There is question, however, regarding the power that the bishop has. Is he to be viewed as a representative of the community or as its ruler? D. M. Reis would prefer to view the bishop with more authority and see him more as a monarchical ruler. He would draw attention to a text such as Letter to the Magnesians 6:1 in which the bishop is declared to "preside in the place of God". He also would appeal to the Letter to the Trallians 3:1 in which the bishop is declared to be the "model of God". He would also note that the bishop's mind closely resembles that of God the Father in Letter to the Ephesians 3:2; 4:1 and Letter to Polycarp 8:1. ${ }^{42}$

While the bishop does have a special spot in Ignatius' mind, one should be careful not to give him too much authority and conceive him to be a monarchical ruler. Within several other passages in Ignatius' writing, there are others within the church who have authority. For example, in Letter to the Magnesians 6:1-2 the presbyter and the deacons also have power.

Since, therefore, in the persons mentioned above I have by faith seen and loved the whole congregation, I have this advice: be eager to do everything in godly harmony, the bishop presiding (prokathemenou) in the place of God and the presbyters in the place of the council of the apostles and the deacons, who are especially dear to me, since they have been entrusted with the ministry of Jesus Christ, who before the ages was with the Father and appeared at the end of time. Let all therefore accept the same attitude as God and respect one another, and let no one regard his neighbor in merely human terms, but in Jesus Christ love one another always. Let there be nothing among you that is capable of dividing you, but be united with the bishop and with those who lead (prokathemenois), as an example and lesson of incorruptibility. ${ }^{43}$

While Ehrman would like to translate prokathèmenos as "preside over" in the latter portion of Letter to the Magnesians 6:2 thereby emphasizing power, Holmes' translation "lead" is to be preferred. ${ }^{44}$ The word prokathêmai within Ignatius' writing does not solely represent power, but it can refer to influence such as the entire congregation which influences a district (cf. Ign. Rom. Sal.).

When authority is considered more broadly within Ignatius' letters, it also extends to other individuals beyond the bishop. For example, in Letter to the Trallians 3.1, the presbyters and the deacons have authority. ${ }^{45}$ This passage reads, "Similarly, would prefer texts such as Ign. Magn. 6:1 in which the bishop is declared to "preside in the place of God". The bishop is the "model of God" in Ign. Trall. 3:1. The bishop's mind closely resembles that of the Father in Ign. Eph. 3:2; 4:1; Ign. Pol. 8:1.

43 Holmes, Apostolic Fathers, 104.

44 Ehrman's translation is as follows in Letter to the Magnesians 6:2. You should assume the character of God an all respect one another. No one should consider his neighbor in a fleshly way, but you should love one another in Jesus Christ at all times. Let there be nothing among you that can divide you, but be unified with the bishop and with those who preside (prokathemenois) according to the model and teaching of incorruptibility. Ehrman, Apostolic Fathers, 247. 
let everyone respect the deacons as Jesus Christ, just as they should respect the bishop, who is a model of the Father, and the presbyters as God's council and as the band of the apostles. Without these no group can be called a church". The bishop and the presbyters also have authority from Letter to the Magnesians 7:1 which states, "Therefore as the Lord did nothing without the Father, either by himself or through the apostles (for he was united with him), so you must not do anything without the bishop and the presbyters". Furthermore, there is accountability to love the rest of the brothers in the church (cf. Ign. Magn. 6:2) ${ }^{46}$

Rather than conceiving of the bishop as being authoritative, the bishop should be seen as preeminent as a representative of the community rather than a ruler as Brent has proposed in his work Cultural Ecumenism and Episcopacy. After Ignatius wrote, the word (prokathèmai) did have a sense of "preside over" (cf. Justin Martyr, 1 Apol. 65:3), but it also has the sense of being pre-eminent. ${ }^{47}$ This should be favored in our understanding of discipleship because in Ignatius' writings, the bishop does not preside over people alone and without qualification. ${ }^{48}$ As Brent concludes, "bishops are 'pre-eminent as a type' because they 'stand out' from the community as signs or ikons of the common community experience of the saving events". ${ }^{49}$

The effect on the discussion of discipleship would lead the Christian at that time to follow the acknowledged representative of the church. Rather than submitting to a monarchical authority, the follower of Christ should follow the preeminent example within the church as a critical means of working out one's Christian life. It would be a characteristic of all to follow the preeminent example rather than deviate from his example (cf. Ign. Magn. 7:1; Ign. Trall. 7:2; Ign. Phld. 4).

Letter to the Magnesians 9:1-2

Later within the Letter to the Magnesians, Ignatius returns to discipleship language. The next mention of discipleship is found following an exhortation not to be deceived by erroneous opinions and old fables (cf. Ign. Magn. 8:1). These are to live according to Judaism..$^{50}$ Instead, the Magnesians are encouraged to be disciples of Jesus Christ by holding fast to the true Christian teaching.

And so those who lived according to the old ways came to a new hope, no longer keeping the Sabbath but living according to the Lord's day, on which our life arose through him and his death—which some deny. Through this mystery we came to believe, and for this

Holmes, Apostolic Fathers, 104-105.

Athanasius, C. Gent. 26; Origen, Cels., 4,63; Basil of Seleucia, Vita Thecl. 1. Cf. A. Brent, Cultural Episcopacy and Ecumenism: Representative Ministry in Church History from the Age of Ignatius of Antioch to the Reformation with Special Reference to Contemporary Ecumenism, SCM 6 (Leiden: Brill, 1992), 81-82.

See how the deacons and presbyters also lead. Cf. Ign. Magn. 6:1-2. Note how in Ignatius' Letter to the Trallians 3:1 the deacons are mentioned before the bishop.

A. Brent, Ignatius of Antioch: A Martyr Bishop and the Origin of Episcopacy (London: Continuum, 2007), 82. Isacson, To Each Their Own Letter, 90-91.

PERICHORESIS 11.1 (2013) 
reason we endure, that we may be found to be disciples of Jesus Christ, our only teacher. How then are we able to live apart from him? Even the prophets who were his disciples in the spirit awaited him as their teacher. And for this reason, the one they righteously respected raised them from the dead when he arrived.

Ignatius exhorts the Magnesians not to live according to Judaism as exhibited by the Sabbath but according to the Lord's day. What is critical from this passage for the disciple is the quality of endurance. Being steadfast to the mystery of the death and resurrection of Jesus Christ is important for being a disciple. Such was the example of the prophets who also waited patiently for him.

\section{Letter to the Romans 3:1-2}

One final passage about discipleship will be considered. This appears within Ignatius' Letter to the Romans in chapter 3. In this section, Ignatius is encouraging the Romans not to stand in the way of his martyrdom. He does so by referring to several variations on the theme of word versus deed (cf. Rom. 2:1).

At no time have you been envious of anyone; instead you have taught others. But my wish is that the instructions you enjoin on others be firm, when you make them disciples (ha mathèteuontes entellesthe). For me, ask only that I have power both inside and out, that I not only speak but also have the desire, that I not only be called a Christian (Christianos) but also be found one. For if I be found a Christian, I can also be called one and then be faithful—when I am no longer visible in the world.

Ignatius reminds the Romans that they have taught others, presumably meaning to endure hardship and suffering. He now urges them to continue this. He also encourages them to follow through on their convictions-doing what they actually said they would. ${ }^{51}$ When they make disciples, they must continue to be firm.

Within the passage Ignatius uses the term Christianos, a term that is closely related to discipleship. The term can be found within his writing to refer to the disciples of Christ in general in several passages. For example in Letter to the Ephesians 14:2, Ignatius states that those professing to be Christians will be seen by what they do (cf. Ign. Magn. 4:1). ${ }^{52}$ Later within Romans 3:3, it will be used generally, when he writes, "The deed is not a matter of persuasive rhetoric, but Christianity (Christianismos) is characterized by greatness when it is hated by the world". ${ }^{3}$

Only one time is the term Christianos used in relation to Ignatius himself and this time in relation to his death. ${ }^{54}$ Since Ignatius uses it personally only once, it can be

51 Schoedel, Ignatius of Antioch, 172-73.

52 It is right not only to be called Christians, but to be Christians. Ign. Magn. 4:1.

53 Mellink, "Death as Eschaton", 201.

54 See other times when it refers to Christians in general, Ign. Eph. 14:2; Ign. Magn. 4:1; 10:1; Ign. Trall. 6:1; Ign. Phil. 6:1; Ign. Pol. 6:1; See further Bommes, Weizen Gottes, 30-38. 
concluded that the faithfulness of his being like Christ is expressed through his death (cf. Ign. Eph. 1:2; Ign. Rom. 4:2; Ign. Pol. 7:1), yet for other Christians it is exhibited by their love, faith, and endurance expressed in the unity of the church. ${ }^{55}$ Ignatius' personal discipleship experience involves following through on his suffering.

\section{Summary of Discipleship Ideas}

While more passages could be examined about discipleship in Ignatius, there are several themes that have emerged. ${ }^{56}$ Most of these agree with the ideas surveyed regarding imitation. Obedience to godly standards is a critical factor for discipleship. Deeds must match words. The quality of endurance to the mystery of the death and resurrection of Jesus is also a key quality for a disciple. Discipleship is displayed by following a preeminent example. Suffering and endurance are also expected within the discipleship experience. ${ }^{57}$ Discipleship also involves maintaining unity. These conclusions are in agreement with the investigation of imitation language in Ignatius.

\section{Conclusion. Ignatius' View of Imitation and Discipleship Read in Conjunction with 1 Corinthians 4 and 11}

If one now brings the ideas of imitation and discipleship from Ignatius to interpret Paul's writing in 1 Corinthians 4:16 and 11:1, there are several things that can be clarified. This will affirm the views of some Corinthian scholars, develop the ideas of others, but then contradict the views of some.

Firstly, the vast majority of ideas associated with imitation and discipleship within Ignatius' writings indicate that a large majority of uses relate these to following God and particularly following the impulse of the cross of Christ. Cross language can be found in the surrounding context of imitation within 1 Corinthians 4 and 11. In 1 Corinthians 4:9-13 Paul writes, "For I think that God has exhibited us apostles as last of all, like men sentenced to death, because we have become a spectacle to the world, to angels, and to men. We are fools for Christ's sake, but you are wise in Christ. We are weak, but you are strong. You are held in honor, but we in disrepute. To the present hour we hunger and thirst, we are poorly dressed and buffeted and homeless, and we labor, working with our own hands. When reviled, we bless; when persecuted, we endure; when slandered, we entreat. We have be-

See Ign. Magn. 9.1; 10.1 for disciples enduring to the end. See further Ign. Eph. 1.2.4; 10:1; Ign. Magn. 9:1-2; 10:1; Ign. Trall. 5:2; Ign. Rom. 4:2; 5:1, 3; Ign. Pol. $2: 1 ; 7: 1$.

Suffering is never far from Ignatius' mind (cf. Ign. Trall. Sal.; Ign. Phld. Sal.; Ign. Smyrn. 1-2). See further Smith, "Ministry, Martyrdom, and Other Mysteries", 51-55.

PERICHORESIS $11.1(2013)$ 
come, and are still, like the scum of the world, the refuse of all things". Such a passage is noted by a number of commentators on 1 Corinthians to concern the cross. ${ }^{58}$ Hays expresses this well when he writes, "Paul regards these experiences not merely as misfortunes or trials to be surmounted but as identifying marks of the authenticity of his apostleship because they manifest his conformity to Christ's sufferings" ${ }^{59}$

Imitation also has a focus on Christ and his sacrifice in 1 Corinthians 11:1. Imitation is focused on Christ in 1 Corinthians 11:1 in that the Corinthians are to imitate Paul just as (kathōs kagō) he imitates Christ. Within the context leading up to 1 Corinthians 11, self-control and self-denial are found. In the passage leading up to 1 Corinthians 11, ideas of self-denial are found within 1 Corinthians 9:12, which says "If others share this rightful claim on you, do not we even more? Nevertheless, we have not made use of this right, but we endure anything rather than put an obstacle in the way of the gospel of Christ (cf. 1 Corinthians 9:15)". Then also, within 1 Corinthians 10:24 Paul denies himself when he writes, "Let no one seek his own good, but the good of his neighbor (cf. 1 Corinthians 8:11, 13)". The qualities of suffering and endurance are raised to the forefront when imitation is interpreted in the light of Ignatius' use of the idea and discipleship. This would be in agreement with the positions taken by Schrage, Stanley, Ciampa, and Rosner.

If Paul is interpreted in the light of the data from Ignatius, the appeal for unity can also be seen within Paul's use of imitation language. Both 1 Corinthians 4:16 and 1 Corinthians 11:1 occur in places following exhortations against division. In 1 Corinthians 1 and 3 Paul has urged the Corinthians not to follow parties connected with different Christian leaders-Paul, Cephas, or Apollos. Following his argument which concludes in 1 Corinthians 3 , he urges the Corinthians to imitate him and his willingness to embrace suffering for the gospel message.

These ideas continue in the context prior to 1 Corinthians 11:1. In this section, Paul was also appealing to a divided community. The Corinthian community was divided over how to handle meat sacrificed to idols. This led to different categories-weak and strong brothers. He addresses both parties within 1 Corinthians 811, and then concludes by urging them to imitate him, someone who is willing to forgo his rights (cf. 1 Corinthians 9:15-23). The connection that imitation has with pursuing unity in Ignatius is also affirmed by others who are examining 1 Corinthians. ${ }^{60}$ A. D. Clarke summarizes this well when he comments on imitation in 1 Corinthians 11:1 with regard to its previous context. He writes that the Corinthians "are not to seek their own good, but the good of the many". ${ }^{61}$ Brief an die Korinther, 342.

59 R. B. Hays, First Corinthians (Louisville: John Knox, 1997), 77.

60 Thiselton, The First Epistle to the Corinthians, 371-73. Ciampa and Rosner, The First Epistle to the Corinthians, 498-99.

61 Clarke, Serve the Community of the Church, 226.

PERICHORESIS $11.1(2013)$ 
Ignatius' use of imitation and discipleship language also helps makes sense of why Paul will encourage the Corinthians to imitate a human being or follow someone rather than God alone. As several passages within Ignatius' writing called for imitating or following people like Onesimus, Burrhus, or Damas the bishop in Magnesia, so Paul uses imitation language to encourage following himself. To follow a preeminent leader of a community who has virtues that align with the cross makes sense when Paul's command of exhortation is interpreted in the light of Ignatius.

Interpreting Paul in the light of Ignatius, however contradicts seeing Paul as claiming fatherly or hierarchical power to enforce his will as Castelli and Reis advocate. While there may be some merit in seeing Paul using imitation language as a preeminent member of the Corinthian community, the number of references to imitation and discipleship within Ignatius point to following the cross of Christ as part of one's call for Christian commitment.

Interpreting Paul in relation to Ignatius would develop Bellville's viewpoint. While she sees Paul's fatherly example as critical for the Corinthians to follow him, imitation language contains much more than a fatherly appeal.

Finally, reading Paul in the light of Ignatius indicates that imitation ideas should not be limited to providing a good example over against those from the GrecoRoman background of Sophistry. While Sophistic practices do seem to have infiltrated the Corinthian community, imitation ideas within Ignatius should not be limited to addressing Sophists as Witherington supposes. If Ignatius is used to interpret Paul, imitation concepts draw on theological ideas that extend to one's view of God and the cross of Christ.

Reading Ignatius has clarified the interpretation of imitation within 1 Corinthians. Further reading sections of the Apostolic Fathers which contain influence from 1 Corinthians will likely aid in the interpretation of imitation as well as other issues within this epistle.

\section{Bibliography}

Belleville, L. "Imitate Me, Just as I imitate Christ': Discipleship in the Corinthian Correspondence". Patterns of Discipleship in the New Testament. Edited by R. N. Longenecker. Grand Rapids: Eerdmans, 1996, 120-142.

Bockmuehl, M. N. Seeing the Word: Refocusing New Testament Study. Grand Rapids: Baker, 2006.

Bommes, K. Weizen Gottes: Untersuchungen zur Theologie des Martyriums bei Ignatius von Antiochien. Köln: Hanstein, 1976.

Brent, A. Cultural Episcopacy and Ecumenism: Representative Ministry in Church History from the Age of Ignatius of Antioch to the Reformation with Special Reference to Contemporary Ecumenism. SCM 6. Leiden: Brill, 1992.

. Ignatius of Antioch: A Martyr Bishop and the Origin of Episcopacy. London: Continuum, 2007. 
Brox, N. Zeuge und Märtyrer. Untersuchungen zur frühchristlichen Zeugnis-Terminologie. SANT 5. München: Kösel, 1961.

Castelli, E. Imitating Paul: A Discussion of Power. Louisville: Westminster/ John Knox, 1991.

Ciampa, R. and B. S. Rosner. The First Epistle to the Corinthians. PNTC. Grand Rapids: Eerdmans, 2010.

Clarke, A. D. “'Be Imitators of Me': Paul's Model of Leadership”. TynBul 49 (1998): 329-60.

. Serve the Community of the Church: Christians as Leaders and Ministers. First Century Christians in the Greco-Roman World. Grand Rapids, MI: Eerdmans, 2000.

Corwin, V. St. Ignatius and Christianity in Antioch. Yale Publications in Religion 1. New Haven: Yale, 1960.

de Boer, P. Imitation of Paul: An exegetical Study. Kampen: Kok, 1962.

Ehrman, B. D. The Apostolic Fathers, Volume 1: I Clement, II Clement, Ignatius, Polycarp, Didache. Translated by B. D. Ehrman. Two volumes. LCL. Cambridge, MA: Harvard, 2003.

Fee, G. The First Epistle to the Corinthians. NICNT. Grand Rapids: Eerdmans, 1987.

Grant, R. M. The Apostolic Fathers: A New Translation and Commentary. Volume 4. New York: Thomas Nelson \& Sons, 1996.

Günther, E. "Zeuge und Märtyrer". ZNW (1956): 145-61.

Foster, P. "The Epistles of Ignatius of Antioch and the Writings that later formed the New Testament". The Reception of the New Testament in the Apostolic Fathers. Edited by A. C. Gregory and C. M. Tuckett, 159-86. Oxford: Oxford University Press, 2005.

Grant, R. M. The Apostolic Fathers: A New Translation and Commentary. Volume 4. New York: Thomas Nelson \& Sons, 1996.

Hafemann, S. J. Suffering and Ministry in the Spirit: Paul's Defense of his Ministry in II Corinthians 2:14-3:3. Grand Rapids: Eerdmans, 1990.

Holmes, M. W. The Apostolic Fathers in English. Translated by M. W. Holmes. Third edition. Grand Rapids: Baker, 2006.

Inge, W. R. "Ignatius". The New Testament in the Apostolic Fathers. Edited by the Oxford Society of Historical Theology, 63-83. Oxford: Clarendon, 1905.

Isacson, M. To Each Their Own Letter: Structure, Themes, and Rhetorical Strategies in the Letters of Ignatius of Antioch. CBNTS 42. Stockholm; Almqvist \& Wiksell International, 2004.

Lake, K. The Apostolic Fathers. Two volumes. LCL. London/ Cambridge, MA: Harvard, 1912.

Lightfoot, J. B. The Apostolic Fathers. Grand Rapids: Baker, 1956.

Mellink, A. "Death as Eschaton: A Study of Ignatius of Antioch's Desire for Death". PhD diss. Universiteit van Amsterdam, 2000.

Oden, T. C. Ancient Christian Commentary on Scripture. Fourteen volumes. Downers Grove: IVP, 1998-2011. 
Preiss, Th. "La mystique de l'imitation du Christ et de l'unité chez Ignace d'Antioch". RHPR 18 (1938): 197-241.

Reis, D. M. "Following in Paul's Footsteps: Mimēsis and Power in Ignatius of Antioch". In Trajectories through the New Testament and the Apostolic Fathers. Edited by A. C. Gregory and C. M. Tuckett, 287-306. Oxford: Oxford University Press, 2005.

Sanders, B. "Imitating Paul: 1 Corinthians 4:16”. HTR 74 (1981): 353-363.

Schlier, H. Religionsgeschichtliche Untersuchungen zu den Ignatiusbriefen. Giessen: A. Töpelmann, 1929.

Schoedel, W. Ignatius of Antioch: A Commentary on the Letters of Ignatius of Antioch. Hermeneia. Philadelphia: Fortress, 1985.

Schrage, W. Der erste Brief an die Korinther. Teilband 1: 1Kor 1,1-6,11. EKK 7. Zürich: Benziger, 1991.

Smith, C. B. "Ministry, Martyrdom, and other Mysteries: Pauline Influence on Ignatius of Antioch". Paul and the Second Century. Edited by M. F. Bird and J. R. Dodson, 37-56. LNTS 412. London: T \& T Clark, 2011.

Stanley, D. M. "Become Imitators of Me: The Pauline Conception of Apostolic Tradition". Biblica 40 (1958): 859-77.

Thiselton, A. C. The First Epistle to the Corinthians. NIGTC. Grand Rapids/ Carlisle: Eerdmans/ Paternoster, 2000.

von Campenhausen, H. Die Idee des Martyriums in der alten Kirche. Göttingen: Vandenhoeck \& Ruprecht, 1964.

Williams, D. H. Retrieving the Tradition and Renewing Evangelicalism. Grand Rapids, MI: Eerdmans, 1999.

Wilkins, M. J. "The Interplay of Ministry, Martyrdom, and discipleship in Ignatius of Antioch". Worship, Theology, and Ministry in the Early Church: Essays in Honor of Ralph P Martin. Edited by M. J. Wilkins and T. Page. JSNTSup 87. Sheffield: JSOT Press, 1992, 294-315.

Witherington, B. Conflict and Community in Corinth: A Socio-Rhetorical Commentary on 1 and 2 Corinthians. Grand Rapids, MI: Eerdmans, 1995. 